\title{
Human papillomavirus: a predictor of better survival in ocular surface squamous neoplasia patients
}

\author{
Sheetal Chauhan, ${ }^{1}$ Seema Sen, ${ }^{1}$ Anjana Sharma, ${ }^{2}$ Lalit Dar, ${ }^{3}$ Seema Kashyap, ${ }^{1}$ \\ Pankaj Kumar, ${ }^{3}$ Mandeep Singh Bajaj, ${ }^{4}$ Radhika Tandon ${ }^{5}$
}

${ }^{1}$ Department of Ocular

Pathology, Dr Rajendra Prasad Centre for Ophthalmic

Sciences, All India Institute of Medical Sciences, New Delhi, India

${ }^{2}$ Department of Microbiology, Dr Rajendra Prasad Centre for Ophthalmic Sciences, All India Institute of Medical Sciences, New Delhi, India

${ }^{3}$ Department of Microbiology, All India Institute of Medical Sciences, New Delhi, India

${ }^{4}$ Ophthalmoplasty Service, Dr Rajendra Prasad Centre for Ophthalmic Sciences, All India Institute of Medical Sciences, New Delhi, India

${ }^{5}$ Cornea and Refractive Surgery Service, Dr Rajendra Prasad

Centre for Ophthalmic

Sciences, All India Institute of Medical Sciences, New Delhi, India

\section{Correspondence to}

Dr Seema Sen, Department of Ocular Pathology, Dr Rajendra Prasad Centre for Ophthalmic Sciences, All India Institute of Medical Sciences, R. no. 725, New Delhi 110029, India; ssenop@rediffmail.com

Accepted 4 August 2012 Published Online First 31 August 2012

\begin{abstract}
Background Although human papillomavirus (HPV) has been implicated in the pathogenesis of ocular surface squamous neoplasia (OSSN), no study has so far dealt with the prognostic role of HPV. In this study the presence and significance of HPV in OSSN and its correlation with p16 $^{\text {INK4a }}$ immunoexpression was determined.
\end{abstract}

Methods HPV was detected by HPV-L1 capsid genespecific multiplex PCR using PGMY09/11 primers, and genotyping was done by linear array on 64 OSSN patients and 15 conjunctival controls. p16 ${ }^{\text {INK4a }}$ immunoexpression as a marker for HPV presence was also evaluated.

Results The HPV genome was detected in $11 \%$ of cases by multiplex PCR, and all positives belonged to a high-risk HPV16 genotype. p16 ${ }^{\text {INK4a }}$ Overexpression was seen in $28 \%(18 / 64)$ of cases. Control conjunctival tissues were negative for HPV and $p^{16^{\text {INK4a }}}$ expression. The presence of HPV was associated with significantly improved disease-free survival $(p=0.02)$ as well as $p 16^{\text {INK4a }}$ overexpression $(p=0.001)$. The sensitivity and specificity of $\mathrm{p} 16^{\mathrm{INK} 4 \mathrm{a}}$ as a marker for HPV presence was $86 \%$ and $79 \%$, respectively, with a positive predictive value of $33 \%$ and a negative predictive value of $98 \%$.

Conclusions The results of this study point towards HPV as a predictor of better survival in a subset of HPV-positive OSSN patients. Although p16 ${ }^{\text {INK4a }}$ immunoexpression is a useful indicator of HPV presence in OSSN, confirmation by multiplex PCR is necessary.

\section{INTRODUCTION}

Ocular surface squamous neoplasia (OSSN) encompasses a spectrum of conjunctival, limbal and corneal neoplasias, which include conjunctival intraepithelial neoplasias (CIN) or dysplasia at the one end to invasive squamous cell carcinoma (SCC) at the other. It is the most common ocular surface tumour and the third most common oculo-orbital tumour after melanoma and lymphoma, with a worldwide incidence ranging between 0.02 and 3.5 per 100000 . Although most of the tumours are localised and slowly growing, they have the capability of causing severe ocular morbidity and mortality if neglected. ${ }^{1-4}$

The pathogenesis of these tumours has been attributed classically to abnormal maturation of the epithelium induced by ultraviolet irradiation in combination with other factors including human papillomavirus (HPV), HIV infection or organ transplant recipients (due to immunosuppression), and in genetically predisposed states, such as xeroderma pigmentosum. ${ }^{1}$
HPV have been associated with a variety of benign and malignant epithelial lesions. High-risk HPV types 16 and 18 have been implicated as aetiological agents for the development of cervical SCC. ${ }^{5}$ Studies on OSSN from different geographical regions have reported wide variation in HPV positivity between $0 \%$ and $100 \% .^{6-10}$ A few published studies from India have shown no association of HPV with OSSN. ${ }^{11-12}$

In HPV-associated tumours, the expression of tumour suppressor protein $\mathrm{p} 16^{\mathrm{INK} 4 \mathrm{a}}$ is increased due to inactivation of retinoblastoma protein by highrisk HPV oncoprotein E7, unlike other cancers in which $\mathrm{p} 16^{\mathrm{INK} 4 a}$ gets inactivated. ${ }^{13} 14$ Overexpression of $\mathrm{p} 16^{\mathrm{INK} 4 \mathrm{a}}$ is therefore considered a reliable marker for HPV-induced cervical intraepithelial neoplasia and head and neck SCC. ${ }^{15}$

The present study was planned to determine the presence and genotype of HPV DNA in OSSN and its association with survival. The utility of p16 $6^{\mathrm{INK} 4 a}$ immunoexpression for predicting HPV in OSSN was also evaluated.

\section{MATERIALS AND METHODS \\ Patient and control group selection}

Sixty-four patients with OSSN (44 SCC, 20 CIN) and 15 controls (conjunctival epithelialectomy tissues from limbal stem cell deficiency patients) from the years $2008-10$ were enrolled in this study and approval was obtained from the institute ethics committee. After obtaining written consent fresh tissues from cases and controls were stored at $-70^{\circ} \mathrm{C}$ for molecular studies, and the remaining tissue was fixed in 10\% neutral buffered formalin and embedded in paraffin wax for histopathological examination and immunohistochemical analysis.

Clinical features including hours of exposure to solar ultraviolet irradiation and the presence of predisposing conditions such as xeroderma pigmentosum were recorded. Radiological details were also recorded.

Haematoxylin-eosin stained sections were examined to confirm the diagnosis of OSSN and the cases were classified as CIN or SCC. The CIN cases were further classified as mild, moderate or severe dysplasia based on the extent of epithelial involvement, and SCC cases were classified as well or poorly differentiated depending on the extent of keratinisation. ${ }^{16}$

\section{Detection of HPV by multiplex PCR}

DNA extraction from all 64 fresh tissue specimens was performed using the OIAamp DNA mini kit (Qiagen, Hilden, Germany) following the 
manufacturer's instructions. The extracted DNA was quantified using a Nanodrop spectrophotometer (Nanodrop Technologies, Wilmington, Delaware, USA). The quality of extracted DNA was determined by $\beta$-globin-specific PCR using GH20/GH21 primer. Briefly, a $40 \mathrm{ng} / \mu \mathrm{l}$ aliquot of genomic DNA was added as a template to a PCR master mixture containing $1 \times$ PCR buffer (100 Mm Tris-HCl, $500 \mathrm{Mm} \mathrm{KCl,} \mathrm{pH} \mathrm{8.3),} 200 \mu \mathrm{M}$ each deoxynucleoside triphosphate, $200 \mathrm{nM}$ primer, $1.5 \mathrm{mM} \mathrm{MgCl}_{2}$ and $2.5 \mathrm{U}$ of Ampli Taq Gold DNA polymerase. PCR was performed using the following conditions: $10 \mathrm{~min}$ at $95^{\circ} \mathrm{C}$, followed by $30 \mathrm{~s}$ at $95^{\circ} \mathrm{C}, 1 \mathrm{~min}$ at $53^{\circ} \mathrm{C}, 1 \mathrm{~min}$ at $72^{\circ} \mathrm{C}$ and $10 \mathrm{~min}$ at $72^{\circ} \mathrm{C}$ for 35 cycles. DNA extracted from all 64 samples and 15 controls was amplified using $\beta$-globin, which showed a product of $450 \mathrm{bp}$, confirming the quality of DNA to be suitable for PCR.

The HPV-L1 capsid gene-specific consensus primer, PGMY09/ 11, which is an improvement for quality assurance was used for HPV detection. This primer detects all the major HPV types. The PCR assay was performed using a $40 \mathrm{ng} / \mu \mathrm{l}$ aliquot of DNA in master mixture containing $1 \times$ PCR buffer, $200 \mu \mathrm{M}$ each deoxynucleoside triphosphate, $200 \mathrm{nM}$ primer, $4.0 \mathrm{mM} \mathrm{MgCl}_{2}$ and $7.5 \mathrm{U}$ of Ampli Taq Gold DNA polymerase. Forty cycles of amplification were performed using the following conditions: $9 \mathrm{~min}$ at $94^{\circ} \mathrm{C}$, followed by $1 \mathrm{~min}$ at $94^{\circ} \mathrm{C}, 1 \mathrm{~min}$ at $55^{\circ} \mathrm{C}$ and $1 \mathrm{~min}$ at $72^{\circ} \mathrm{C}$.

For each reaction, DNA extracted from CaSki (HPV16) and HeLa (HPV18) cell lines served as positive and C33A (HPV negative) cell line and deionised water instead of the DNA template served as a negative control for HPV-specific PCR assay.

\section{HPV genotyping by linear array}

Genotyping of positive samples was done using the HPV linear array kit (Roche Molecular System, Branchburg, New Jersey, USA) following the manufacturer's instructions. Briefly, DNA was isolated and for each reaction, $20 \mu \mathrm{l}$ of extracted DNA was subjected to PCR amplification using the HPV consensus PCR (Roche Molecular Systems Inc., Alameda, California, USA).This method utilises biotinylated primers (PGMYO9/PGMY11) that amplify a $450 \mathrm{bp}$ fragment of the $\mathrm{L} 1$ open reading frame of 37 HPV genotypes. A control set of biotinylated primers simultaneously amplifies a $268 \mathrm{bp}$ fragment of the human $\beta$-globin gene in each reaction. PCR products were then denatured and hybridised to separate HPV genotyping strips containing an immobilised array of 37 different HPV probes. Hybridised PCR products were visualised by using a streptavidin-horseradish peroxidase detection system. Negative and positive controls (provided in the kit) were run with each batch of specimens tested.

\section{P16 $^{\text {INK4a }}$ immunohistochemistry}

Immunohistochemistry for $\mathrm{p} 16^{\mathrm{INK} 4 \mathrm{a}}$ was performed on 64 cases and 15 control conjunctival tissues. Unstained sections of 4-5 $\mu \mathrm{m}$ thickness were cut on polylisine-coated slides from the formalin-fixed paraffin-embedded tissues and subjected to immunohistochemical analysis using the avidin-biotin indirect method. Briefly, sections were deparaffinised in xylene, dehydrated and subjected to heat antigen retrieval in citrate buffer ( $\mathrm{pH}$ 6.0) for $20 \mathrm{~min}$. Endogenous peroxidase activity was blocked by $3 \% \mathrm{H}_{2} \mathrm{O}_{2}$. The slides were incubated with primary mouse IgG2b against $\mathrm{p} 16^{\text {INK4a }}$ (clone $6 \mathrm{H} 12$ : prokaryotic recombinant fusion protein corresponding to the entire human p16 ${ }^{\text {INK4a }}$ molecule) obtained from Novocastra Laboratories Ltd. (UK) at a dilution of $1: 50$ in a humidified chamber at $4^{\circ} \mathrm{C}$ overnight, followed by incubations with biotinylated-linked secondary antibody and peroxidase labelled streptavidin (Dako
Cytomation LSAB+System-HRP kit). The sections were visualised using $3,3^{\prime}$-diaminobenzidene peroxidase substrate for 3-4 min, then counterstained with haematoxylin and examined by light microscopy. $\mathrm{p} 16^{\mathrm{INK} 4 \mathrm{a}}$-positive cervical SCC served as a positive control. Primary antibody was replaced by Tris-buffered saline in the negative control. Immunoreactivity was considered positive when more than $10 \%$ of the cells showed nuclear as well as cytoplasmic positivity. ${ }^{17} 18$

\section{Statistical analysis}

Statistical analysis was performed with Windows SPSS V.11.0. The relationship between HPV, p16 ${ }^{\mathrm{INK} 4 \mathrm{a}}$ status and clinicopathological variables such as age, sex, laterality, surgical intervention, histopathological differentiation, and tumour size, orbital and intraocular invasion was evaluated using a contingency table, and further analysed using Fisher's exact test.

p16 ${ }^{\text {INK4a }}$ Immunostaining was evaluated in terms of sensitivity, specificity and predictive value of the test for detecting HPV. The $\kappa$ statistics was used to assess the degree of agreement between $\mathrm{p} 16^{\mathrm{INK} 4 \mathrm{a}}$ and HPV tests. $\kappa$ Values between 0.40 and 0.75 are regarded as fair to good agreement beyond chance, values less than 0.40 as poor agreement beyond chance, and values greater than 0.75 as excellent agreement beyond chance. Disease-free survival curves were constructed using the KaplanMeier method and compared using the log-rank test.

\section{RESULTS}

\section{Clinical and histopathology features}

The mean age of the 64 OSSN patients was $64 \pm 16$ years (6-84 years) with a marked male preponderance (male: female $3.6: 1)$. Limbus was involved in 35 of 64 cases $(54.6 \%)$. The duration of disease varied between 4 months and 10 years (mean 2.3 \pm 2.3 years). A history of sunlight exposure greater than $5 \mathrm{~h}$ was observed in 41 of $64(64 \%)$ patients. The majority of the patients $(84.3 \%)$ came from a poor socioeconomic background (below the poverty line). A history of associated ocular pathology was present in 10 patients (pterygium, ptosis naevus, cyst excision, cataract surgery), and six gave a history of ocular trauma to the affected eye. Three patients had xeroderma pigmentosum and none was an organ transplant recipient. Radiologically, orbital invasion was present in 18 of 64 (28\%). Wide surgical excision was performed in $46(72 \%)$ and the rest underwent exenteration for extensive disease. Gross examination revealed a tumour diameter of $0.4-6.0 \mathrm{~cm}$ (mean $2.4 \pm 1.9 \mathrm{~cm}$ ), and on light microscopy $69 \%$ (44/64) were SCC cases ( 22 well and 22 poorly differentiated) and 20 of 64 (31\%) were CIN cases (seven mild, six moderate and seven severe dysplasia). Intraocular invasion was seen in six of $64(10 \%)$ cases (tables 1-4).

\section{Clinical outcome}

Follow-up data were available in 48 (75\%) OSSN cases over a period of 16-36 months (median 22 months). Recurrence developed in eight $(17 \%)$ patients, lymph node metastasis in four $(8.3 \%)$ and tumour-related deaths in four (8.3\%). All four patients with SCC who died had a tumour size greater than $3 \mathrm{~cm}$ with orbital involvement.

\section{Multiplex PCR and HPV genotyping results}

HPV DNA was detected in seven out of 64 cases $(11 \%)$ using PGMY09/11 consensus primer mediated PCR assay. Of the seven HPV-positive cases, four were SCC patients (two well and two poorly differentiated) and three had CIN (one 
Table 1 Association of HPV with location of OSSN

\begin{tabular}{|c|c|c|c|c|c|}
\hline $\begin{array}{l}\text { Clinical } \\
\text { appearance } \\
(n=64)\end{array}$ & $\begin{array}{l}\text { HPV } \\
\text { positive } \\
(n=7)\end{array}$ & $\begin{array}{l}\text { HPV } \\
\text { negative } \\
(n=57)\end{array}$ & $\begin{array}{l}\text { Location } \\
(n=64)\end{array}$ & $\begin{array}{l}\text { HPV } \\
\text { positive } \\
(n=7)\end{array}$ & $\begin{array}{l}\text { HPV } \\
\text { negative } \\
\text { ( } n=57)\end{array}$ \\
\hline $\begin{array}{l}\text { Fungating mass } \\
\text { (14) }\end{array}$ & 4 & 10 & Limbus (35) & 2 & 33 \\
\hline Nodular (14) & 2 & 12 & $\begin{array}{l}\text { Bulbar } \\
\text { conjunctiva } \\
\text { (6) }\end{array}$ & 4 & 2 \\
\hline Gelatinous (13) & 0 & 13 & $\begin{array}{l}\text { Palpebral } \\
\text { conjunctiva } \\
\text { (15) }\end{array}$ & 0 & 15 \\
\hline Leucoplakic (9) & 0 & 9 & $\begin{array}{l}\text { Medial } \\
\text { canthus (6) }\end{array}$ & 1 & 5 \\
\hline Ulcerative1 (11) & 0 & 11 & & & \\
\hline Papillomatous (3) & 1 & 2 & & & \\
\hline p Value 0.06 (NS) & & & & $\mathrm{p}$ Value* & 0002 \\
\hline
\end{tabular}

*Fisher's exact test.

HPV, human papillomavirus; NS, not significant; OSSN, ocular surface squamous neoplasia.

moderate and two severe dysplasia). All the 15 conjunctival controls were negative for HPV.

Of the $37 \mathrm{HPV}$ genotypes screened by linear array, only HPV16 was detected in the seven HPV-positive OSSN cases that were analysed (figures 1 and 2).

Table 2 Correlation of HPV with clinical features in OSSN

\begin{tabular}{|c|c|c|c|c|}
\hline $\begin{array}{l}\text { Clinical } \\
\text { characteristics }\end{array}$ & $\begin{array}{l}\text { Total } \\
(n=64)\end{array}$ & $\begin{array}{l}\text { HPV positive } \\
(n=7)\end{array}$ & $\begin{array}{l}\text { HPV negative } \\
(\mathrm{n}=57)\end{array}$ & p Value* \\
\hline \multicolumn{5}{|l|}{ Age, years } \\
\hline$\leq 50$ & $18(28 \%)$ & 4 & 8 & \multirow[t]{2}{*}{0.6 (NS) } \\
\hline$>50$ & $46(72 \%)$ & 3 & 25 & \\
\hline \multicolumn{5}{|l|}{ Sex } \\
\hline Male & $50(78 \%)$ & $4(8 \%)$ & $46(92 \%)$ & \multirow[t]{2}{*}{0.8 (NS) } \\
\hline Female & $14(22 \%)$ & $3(21 \%)$ & $11(79 \%)$ & \\
\hline \multicolumn{5}{|l|}{ Laterality } \\
\hline Left & $41(64 \%)$ & $37(90 \%)$ & $4(10 \%)$ & \multirow[t]{2}{*}{0.7 (NS) } \\
\hline Right & $23(36 \%)$ & $3(13 \%)$ & $20(87 \%)$ & \\
\hline \multicolumn{5}{|c|}{ Sunlight exposure, hours } \\
\hline$>5$ & $41(64 \%)$ & $5(12 \%)$ & $36(88 \%)$ & \multirow[t]{2}{*}{0.9 (NS) } \\
\hline$<5$ & $23(36 \%)$ & $2(9 \%)$ & $7(91 \%)$ & \\
\hline \multicolumn{5}{|c|}{ Socioeconomic status } \\
\hline Poor & $54(84 \%)$ & $7(13 \%)$ & $47(87 \%)$ & \multirow[t]{2}{*}{0.6 (NS) } \\
\hline Others & $10(16 \%)$ & $0(0 \%)$ & $10(100 \%)$ & \\
\hline \multicolumn{5}{|c|}{ History of past injury } \\
\hline Yes & $6(9 \%)$ & $0(0 \%)$ & $6(100 \%)$ & \multirow[t]{2}{*}{0.9 (NS) } \\
\hline No & $58(91 \%)$ & $7(12 \%)$ & $51(88 \%)$ & \\
\hline \multicolumn{5}{|c|}{ Associated ocular pathology } \\
\hline Yes & $13(20 \%)$ & $0(0 \%)$ & $13(100 \%)$ & \multirow[t]{2}{*}{0.3 (NS) } \\
\hline No & $41(80 \%)$ & $7(17 \%)$ & $34(36 \%)$ & \\
\hline \multicolumn{5}{|c|}{ Surgical intervention } \\
\hline Biopsy & $46(72 \%)$ & $3(7 \%)$ & $43(97 \%)$ & \multirow[t]{2}{*}{0.09 (NS) } \\
\hline Exenteration & $18(28 \%)$ & $4(22 \%)$ & $14(78 \%)$ & \\
\hline \multicolumn{5}{|l|}{ Metastasis $†$} \\
\hline Present & $4(6 \%)$ & $0(0 \%)$ & $4(100 \%)$ & \multirow[t]{2}{*}{0.9 (NS) } \\
\hline Absent & $60(94 \%)$ & $4(7.0 \%)$ & $56(93 \%)$ & \\
\hline
\end{tabular}

*Fisher's exact test.

†Metastasis: lymph node metastasis.

HPV, human papillomavirus; NS, not significant; OSSN, ocular surface squamous neoplasia.
Table 3 HPV and histopathological features of OSSN

\begin{tabular}{|c|c|c|c|}
\hline Characteristics & HPV positivity $(n=7)$ & HPV negative $(n=57)$ & p Value* \\
\hline \multicolumn{4}{|c|}{ Histopathological diagnosis } \\
\hline $\operatorname{SCC}(n=44)$ & 4 & 40 & 0.7 (NS) \\
\hline $\operatorname{CIN}(n=20)$ & 3 & 17 & \\
\hline \multicolumn{4}{|c|}{ Orbital or intraocular invasion } \\
\hline Present $(n=24)$ & 4 & 20 & 0.4 (NS) \\
\hline Absent $(n=40)$ & 3 & 37 & \\
\hline \multicolumn{4}{|l|}{ Tumour size, cm } \\
\hline$\leq 1(n=27)$ & 1 & 26 & \\
\hline$>1(n=37)$ & 6 & 31 & 0.2 (NS) \\
\hline
\end{tabular}

*Fisher's exact test.

CIN, conjunctival intraepithelial neoplasias; HPV, human papillomavirus; NS, not significant; OSSN, ocular surface squamous neoplasia; SCC, squamous cell carcinoma.

\section{Association of HPV positivity with clinicopathological parameters}

Survival curves of 48 OSSN patients by Kaplan-Meir analysis showed a significantly improved disease-free survival in HPVpositive OSSN cases $(p=0.02)$ (figure 3 ).

Both bulbar as well as limbal conjunctival locations of OSSN significantly correlated with HPV presence $(p=0.0002)$. However, no statistically significant association was observed between HPV presence and any other clinicopathological feature (tables 1-3).

\section{Correlation of $\mathbf{p 1 6}^{\text {INK4a }}$ immunoexpression with HPV in OSSN}

Six of the seven HPV-positive cases showed p16 ${ }^{\mathrm{INK} 4 \mathrm{a}}$ expression (figure 4). However, of the $28 \%(18 / 64)$ of OSSN cases positive for $\mathrm{p} 16^{\mathrm{INK} 4 \mathrm{a}}$ only $33 \%(6 / 18)$ were HPV positive. This correlation between $\mathrm{p} 16^{\mathrm{INK} 4 \mathrm{a}}$ expression and HPV positivity was found to be statistically significant $(p=0.001)$. p16 ${ }^{\mathrm{INK} 4 a}$ Overexpression demonstrated $86 \%$ sensitivity and $79 \%$ specificity in detecting HPV, with a positive predictive value of $33 \%$ and a negative predictive value of $98 \%$. The agreement between the two tests for HPV detection ( $\mathrm{p} 16 \mathrm{INK} 4 \mathrm{a}$ and linear array) was found to be fair $(\mathrm{k}=0.4)$. All 15 control conjunctival tissues were negative for HPV (table 4).

\section{DISCUSSION}

In the multifactorial aetiology and pathogenesis of OSSN the contribution of HPV remains unresolved. Despite several studies over the past three decades on HPV detection in OSSN by PCR, very few have used fresh tumour tissue. ${ }^{9} 19$ The HPV positivity in those studies has shown a marked variation (0-100\%), which could be due to geographical factors, differences in sample storage, PCR conditions or nature of tissues (swab or biopsy). ${ }^{7-10}$ The sensitivity and specificity of PCR is also influenced by PCR design (nested, broad spectrum or type specific) and the size of the amplified product. Most published series have used MY09/11

Table 4 p16 $6^{\text {INK4a }}$ Immunoexpression in OSSN and correlation with HPV

\begin{tabular}{lllc}
\hline & No of cases & \multicolumn{2}{c}{ 16 $^{\text {INK4a }}$ immunostaining } \\
\hline HPV positive & 7 & Positive & Negative \\
HPV negative & 57 & 6 & 1 \\
p Value* & & 12 & 45 \\
\hline
\end{tabular}

*Fisher's exact test.

HPV, human papillomavirus; OSSN, ocular surface squamous neoplasia. 


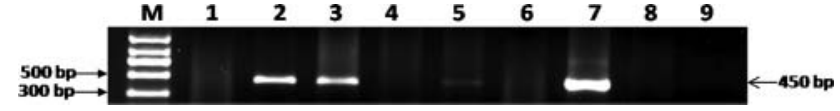

Figure 1 PCR amplification of HPV L-1 consensus showing the amplimer of $450 \mathrm{bp}$. Lane 1: Negative control $\left(\mathrm{dH}_{2} \mathrm{O}\right)$, Lane 2: HPV positive cell line (Hela DNA), Lane 3-7: OSSN samples. Lane 3,5 and 7 shows HPV positive cases, Lane 8: HPV negative cell line (C33a DNA), Lane 9: Control conjunctival tissue, Lane M: 100 bp DNA molecular weight marker.

\begin{tabular}{|c|c|c|}
\hline$\perp$ & II & 1 \\
\hline 11 & $\Perp$ & 2 \\
\hline$\perp$ & $\Perp$ & 3 \\
\hline$\perp$ & 1 & 4 \\
\hline$\perp$ & $\Perp$ & 5 \\
\hline 11 & 11 & 6 \\
\hline$\perp$ & II & 8 \\
\hline - & & 9 \\
\hline 11 & $\Perp$ & 11 \\
\hline
\end{tabular}

Figure 2 Identification of human papillomavirus (HPV) genotypes in ocular surface squamous neoplasia using linear array. HPV16 was detected in cases 2 and 6 .

or GP5/6 consensus primers in OSSN. ${ }^{9}{ }^{10}$ Earlier studies from India on formalin-fixed paraffin-embedded samples did not show any association between OSSN and HPV by PCR or immunohistochemistry. ${ }^{11} 12$

In the present study, therefore, we used more specific and sensitive multiplex PCR (PGMY09/11 primer) on fresh tumour tissues from OSSN cases. This improved PGMY09/11 primer has a greater potential to detect both the newer HPV types as well as the classic genital HPV types. ${ }^{20}$ HPV has been detected on formalin-fixed paraffin-embedded tissues by linear array in head and neck cancer and retinoblastoma cases. In retinoblastoma the detection rate was $14 \%$ in archival tissues as compared to $58 \%$ in fresh cases. ${ }^{21} 22$

As most studies on HPV genotyping in OSSN are limited to detect only a few high-risk types, we encompassed a wide spectrum of as many as 37 genotypes by linear array, including the major high-risk types. HPV16 was detected in $11 \%$ of our OSSN cases with a positivity of $9 \%$ in SCC patients and 15\%

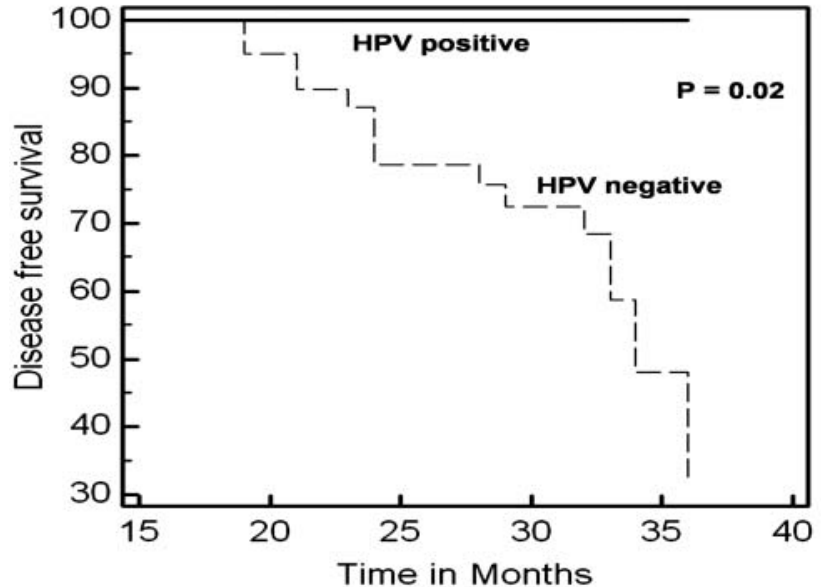

Figure 3 Kaplan-Meier survival curves for disease-free survival stratified according to the human papillomavirus (HPV) infection in patients with ocular surface squamous neoplasia. The disease-free survival rate of the HPV-positive group was significantly better $(p=0.02)$.

in dysplastic cases. Although earlier studies have also demonstrated HPV16 in OSSN, ${ }^{6}{ }^{23}$ others have demonstrated HPV18 as well as multiple genotypes in their cases. ${ }^{8}{ }^{9}$ However, multiple high-risk-HPV types are reported more commonly in cervical neoplasia. ${ }^{24}$

Although the incidence of orbital and intraocular invasion was higher in this study (38\%) compared to $2-13 \%$ reported by others, ${ }^{25}$ survival analysis revealed HPV16-positive OSSN cases to have a better overall survival. Improved survival in HPV-positive cases has earlier been reported in cervical, head and neck, as well as oral carcinoma; ${ }^{26-28}$ however, to the best of our knowledge this is the first study to report the impact of HPV on the survival of OSSN patients.

Overexpression of $\mathrm{p} 16^{\mathrm{INK} 4 \mathrm{a}}$ in OSSN in our study was significantly associated with HPV positivity unlike histologically normal conjunctival tissues, which were negative both for HPV as well as p16 $6^{\mathrm{INK} 4 a}$. Although Auw-Haedirich et $\mathrm{al}^{29}$ have reported HPV and p16 $6^{\text {INK4a }}$ positivity in CIN; they did not observe any association between $\mathrm{p} 16^{\mathrm{INK} 4 \mathrm{a}}$ and HPV. In another study by Kuo et $\mathrm{al}^{30}$ the absence of $\mathrm{p} 16{ }^{\mathrm{INK} 4 a}$ expression was observed in both HPV-positive CIN cases as well as HPV-negative normal conjunctiva. Both those studies had limitations of small sample size and SCC cases were not included in the study. Recent studies in cervical, head-neck, oral SCC and intraepithelial neoplasia have revealed $\mathrm{p} 16^{\text {INK4a }}$ to be a biomarker for high-risk-HPV detection. $^{31} 32$
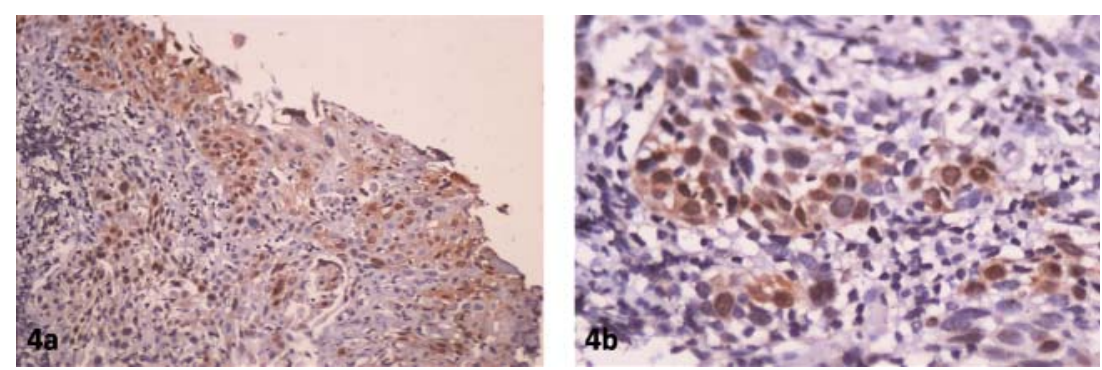

Figure 4 p16 ${ }^{\text {INK4a }}$ immunostaining to show strong nuclear and cytoplasmic positivity in a case of squamous cell carcinoma (a and b) (magnifications $\times 200$ and $\times 400$ ). 
In conclusion, HPV16 DNA was detected in a subset of OSSN cases with improved disease-free survival. The clinical relevance of this observation needs to be validated in a larger HPV-positive OSSN patient cohort. Although $16^{\mathrm{INK} 4 \mathrm{a}} \mathrm{immu}$ noexpression in OSSN patients suggests HPV presence, the same needs to be confirmed by sensitive multiplex PCR.

Contributors SC carried out the experiments, analysed data and drafted the article. SS and AS conceived and designed the study, revised the article critically for intellectual content and approved final version to be submitted. LD provided support in carrying out diagnostic tests, results analysis and revising article. SK contributed to analysis and interpretation of data as well as drafting the article. PK provided assistance in standardising experiments and data analysis. MSB and RT contributed substantially in the acquisition of clinical data and drafting the article.

Funding This study was financially supported by an intramural grant from the All India Institute of Medical Sciences, New Delhi. SC is grateful to the Indian Council of Medical Research, New Delhi, for providing a senior research fellowship.

Competing interests None.

Patient consent Obtained.

Ethics approval Ethics approval was obtained from the institute ethics committee, AllMS (New Delhi).

Provenance and peer review Not commissioned; externally peer reviewed.

\section{REFERENCES}

1. Lee GA, Hirst LW. Ocular surface squamous neoplasia. Surv Ophthalmol 1995;39:429-50

2. Lee GA, Hirst LW. Retrospective study of ocular surface squamous neoplasia. Aust NZ J Ophthalmol 1997:25:269-76.

3. Mahoney MC, Burnett WS, Majerovics A, et al. The epidemiology of ophthalmic malignancies in New York State. Ophthalmology 1990;97:1143-7.

4. Ogun G0, Ogun OA, Bekibele CO, et al. Intraepithelial and invasive squamous neoplasms of the conjunctiva in Ibadan, Nigeria: a clinicopathological study of 46 cases. Int Ophthalmol 2009;29:401-9.

5. Nakamura Y, Mashima Y, Kameyama K, et al. Detection of human papillomavirus infection in squamous tumours of the conjunctiva and lacrimal sac by immunohistochemistry, in situ hybridisation, and polymerase chain reaction. Br J Ophthalmol 1997:81:308-13.

6. McDonnell JM, McDonnell PJ, Stout WC, et al. Human papillomavirus DNA in a recurrent squamous carcinoma of the eyelid. Arch Ophthalmol 1989:107:1631-4.

7. Guthoff R, Marx A, Stroebel P. No evidence for a pathogenic role of human papillomavirus infection in ocular surface squamous neoplasia in Germany. Curr Eye Res 2009;34:666-71.

8. $\quad \mathbf{u} \mathbf{J J}$, Fu P, Pink JJ, et al. HPV infection and EGFR activation/alteration in HIV-infected East African patients with conjunctival carcinoma. PLoS ONE 2010;5:e10477.

9. Simbiri KO, Murakami M, Feldman $\mathrm{M}$, et al. Multiple oncogenic viruses identified in ocular surface squamous neoplasia in HIV-1 patients. Infect Agents Cancer 2010;5:6

10. Asadi-Amoli F, Heidari AB, Jahanzad I, et al. Detection of human papillomavirus in squamous cell carcinoma of conjunctiva by nested PCR: a case control study in Iran. Acta Med Iran 2011;49:707-14.

11. Sen S, Sharma A, Panda A. Immunohistochemical localization of human papilloma virus in conjunctival neoplasias: a retrospective study. Indian J Ophthalmol 2007;55:361-3.
12. Manderwad GP, Kannabiran C, Honavar SG, et al. Lack of association of high-risk human papillomavirus in ocular surface squamous neoplasia in India. Arch Pathol Lab Med 2009;133:1246-50.

13. Samama B, Lipsker D, Boehm N. p16 expression in relation to human papillomavirus in anogenital lesions. Hum Pathol 2006;37:513-19.

14. Klaes R, Friedrich T, Spitkovsky D, et al. Overexpression of p16(INK4A) as a specific marker for dysplastic and neoplastic epithelial cells of the cervix uteri. Int J Cancer 2001:92:276-84

15. Sano T, Masuda N, Oyama T, et al. Overexpression of p16 and p14ARF is associated with human papillomavirus infection in cervical squamous cell carcinoma and dysplasia. Pathol Int 2002;52:375-83.

16. Spencer WH. Conjunctiva. In: Spencer WH, ed. Ophthlamic pathology; an atlas and textbook. 4th ed. Philadelphia: WB Saunders, 1996:113-16.

17. Benevolo M, Mottolese M, Marandino F, et al. Immunohistochemical expression of p16(INK4a) is predictive of HR-HPV infection in cervical low-grade lesions. Mod Pathol 2006; 19:384-91.

18. Agoff SN, Lin P, Morihara J, et al. p16(INK4a) expression correlates with degree of cervical neoplasia: a comparison with Ki-67 expression and detection of high-risk HPV types. Mod Pathol 2003;16:665-73.

19. Ateenyi-Agaba C. Conjunctival squamous-cell carcinoma associated with HIV infection in Kampala, Uganda. Lancet 1995; 345:695-6.

20. Coutlée $\mathbf{F}$, Gravitt P, Kornegay J, et al. Use of PGMY primers in L1 consensus PCR improves detection of human papillomavirus DNA in genital samples. J Clin Microbiol 2002;40:902-7.

21. Black CC, Bentley HA, Davis TH, et al. Use of a linear array for the detection of human papillomavirus genotypes in head and neck cancer. Arch Pathol Lab Med 2010;134:1813-17.

22. Anand B, Ramesh C, Appaji L, et al. Prevalence of high-risk human papillomavirus genotypes in retinoblastoma. Br J Ophthalmol 2011;95:1014-18.

23. Palazzi MA, Erwenne CM, Villa LL. Detection of human papillomavirus in epithelial lesions of the conjunctiva. Sao Paulo Med J 2000;118:125-30

24. Cuschieri KS, Cubie HA, Whitley MW, et al. Multiple high risk HPV infections are common in cervical neoplasia and young women in a cervical screening population. J Clin Pathol 2004:57:68-72.

25. McKelvie PA, Daniell M, McNab A, et al. Squamous cell carcinoma of the conjunctiva: a series of 26 cases. Br J Ophthalmol 2002;86:168-73.

26. Huang L-W, Chao S-L, Hwang J-L. Human papillomavirus-31-related types predict better survival in cervical carcinoma. Cancer 2004;100:327-34.

27. Furniss CS, McClean MD, Smith JF, et al. Human papillomavirus 16 and head and neck squamous cell carcinoma. Int J Cancer 2007;120:2386-92.

28. Zhao $\mathbf{D}, \mathrm{Xu} \mathbf{Q}, \mathrm{Chen} \mathrm{X}$, et al. Human papillomavirus as an independent predictor in oral squamous cell cancer. Int J Oral Sci 2009;1:119-25.

29. Auw-Haedrich C, Martin G, Spelsberg H, et al. Expression of p16 in conjunctival intraepithelial neoplasia does not correlate with HPV infection. Open Ophthalmol J 2008:2:48-56.

30. Kuo K-T, Chang H-C, Hsiao C-H, et al. Increased Ki-67 proliferative index and absence of P16INK4 in CIN-HPV related pathogenic pathways different from cervical squamous intraepithelial lesion. $\mathrm{Br} J \mathrm{Ophthalmol}$ 2006;90:894-9

31. Benevolo M, Mottolese M, Marandino F, et al. Immunohistochemical expression of p16(INK4a) is predictive of HR-HPV infection in cervical low-grade lesions. Mod Pathol 2006:19:384-91.

32. Fregonesi PAG, Teresa DB, Duarte RA, et al. p16(INK4A) immunohistochemical overexpression in premalignant and malignant oral lesions infected with human papillomavirus. J Histochem Cytochem 2003;51:1291-7. 